\title{
The lugworm (Arenicola marina) pump: characteristics, modelling and energy cost
}

\author{
Hans Ulrik Riisgård*, Inge Berntsen, Britta Tarp \\ Institute of Biology, Odense University, Campusvej 55, DK-5230 Odense M, Denmark
}

\begin{abstract}
The lugworm Arenicola marina was studied in an observation aquarium; the typical undisturbed stroke frequency of the piston pump was $f=6$ to 7 strokes $\min ^{-1}$ A new experimental setup was used for direct measurement of volume flow at zero and different imposed back pressures. The back pressure characteristic was a nonlinear function, the stroke frequency being reduced with increasing imposed back pressure, attaining a maximal pressure head of $20 \mathrm{~cm} \mathrm{H}_{2} \mathrm{O}$, which is 30 to 150 times higher than previously found in filter-feeding macro-invertebrate pumps. The back pressure volume flow characteristic was modelled. At the (assumed) normal operation pressure $\left(5 \mathrm{~cm}_{2} \mathrm{O}\right)$ the power output from the 'standard' $(0.5 \mathrm{~g}$ dry $w \mathrm{t})$ lugworm pump was calculated to be $P_{\mathrm{p}}=12.6 \mu \mathrm{W}$. The respiration rate $\left(R_{1} \mu l \mathrm{O}_{2} \mathrm{~h}^{-1}\right)$ measured in lugworms kept in glass tubes was dependent on the stroke frequency and correlated with dry weight $(W, g)$ according to $R=a W^{b}$, where $a=344$ and $b=0.64$ at $f=7$ strokes $\mathrm{min}^{-1}$. The total respiration of the 'standard' worm was $R_{\mathrm{tol}}=232 \mu \mathrm{l} \mathrm{O}_{2} \mathrm{~h}^{-1}=1281 \mu \mathrm{W}$, and thus the overall pump efficiency was $\mu=P_{\mathrm{p}} / R_{\mathrm{tot}}=1 \%$ which suggests that the energy cost of pumping is modest $(<5 \%)$. The volume of water pumped per ml oxygen consumed was only $0.4 \mathrm{l} \mathrm{ml}^{-1} \mathrm{O}_{2}$ which is $>100$ times lower than values previously found for true filter-feeders. This very low value shows that it is unlikely that the lugworm can live by filter-feeding.
\end{abstract}

KEY WORDS: Pumping costs $\cdot$ Ventilatory flow rate $\cdot$ Piston stroke frequency $\cdot$ Respiration rate $\cdot$ Filterfeeding

\section{INTRODUCTION}

The feeding biology of the lugworm Arenicola marina has been studied and debated for many years (Newell 1948, Krüger 1959, Jacobsen 1967, Hobson 1967, Seymour 1971, De Wilde \& Berghuis 1979, Rijken 1979, Pollack 1979). The mode of life and the principal food of the lugworm still seem to be unclarified. Generally, the lugworm is regarded as a non-selective deposit-feeder which is nourished by the swallowing of relatively large amounts of sediments with low nutritive value (Cadée 1976). The pumping activity of the lugworm leads to a tail-to-head directed ventilatory water flow through the J-shaped tube, resulting in an upward flow of water in the sediment in front of the head (e.g. Wells 1949a, b, 1951, 1961, 1966). It has been suggested that the flow of water through the sediment stimulates the growth of microorganisms which

·E-mail: fjordlab@dou.dk are later eaten by the lugworm, cf, the concept of microbial 'gardening' in Abarenicola pacifica and $A$. vagabunda (Hylleberg 1975). A suspension-feeding way of life has also been suggested for the lugworm, because the sediment in front of the head may act as a filter which retains suspended food particles in the inhalant ventilatory water (Krüger 1959, 1962, 1964). No persuasive documentation of the potential quantitative role of a suspension-feeding mode of life has hitherto been given.

During the last 10 yr a number of pumps in filterfeeding marine macro-invertebrates have been analysed: sponges (Riisgård et al. 1993, Larsen \& Riisgård 1994); polychaetes (Riisgård 1989, Riisgård \& Ivarsson 1990, Riisgård et al. 1992, Riisgård 1994); bivalves (Jørgensen et al. 1986a); and ascidians (Riisgård 1988). The pumps were characterized by means of engineering principles and analyses of the energetics of the biological filter-pumps. It was found that the useful pump work constitutes from 0.3 to $4 \%$ of the total metabolic 
expenditure for the various taxonomic groups examined (see review by Riisgård \& Larsen 1995). Referring to Van Dam (1937), Foster-Smith (1978), Baumfalk (1979) and Toulmond \& Dejours (1994), the performance of the lugworm piston pump may decisively deviate from the high-pumping-rate, low-pressure and low-energy pumps which are characteristic of filterfeeding invertebrates.

The aim of the present work was to characterize the Arenicola marina pump and to compare its energy cost and performance with the filter-pumps of suspensionfeeders. Such a comparison study may reveal important features in the characteristics and performance of the lugworm pump, indicating specific adaptations to its feeding biology and general mode of life.

\section{MATERIALS AND METHODS}

Collection. Lugworms Arenicola marina were collected from a tidal mud flat at Bregnør Bugt, Odense Fjord, Denmark, and brought to the nearby Fjord Biological Laboratory, Kerteminde, and placed in an aquarium with sediment and running seawater $\left(15^{\circ} \mathrm{C}\right.$, 16 to $20 \%$ S) until experiments could be performed.

Pumping activity. The normal undisturbed feeding behaviour and the function of the ventilatory piston pump of Arenicola marina was studied in an observation aquarium in which the worm was allowed to establish its natural burrow within a $0.5 \mathrm{~cm}$ thick sediment layer between the outside glass wall of the aquarium and an extra inner glass wall (Fig. 1). The stroke frequency $\left(f\right.$, strokes $\left.\mathrm{min}^{-1}\right)$ of the peristaltic tail-to-head moving pumping wave of the lugworm muscular piston pump (Fig. 2) was counted in a number of individuals by visual observation every $15 \mathrm{~min}$ during $4 \mathrm{~h}$ to determine the undisturbed pumping activity. This 'normal pumping activity' was used as the reference state in the analysis of the lugworm pump

Pump performance. The experimental setup for measurement of volume flow $\left(Q, \mathrm{ml} \mathrm{min}{ }^{-1}\right)$ at zero and different imposed back-pressures $\left(\Delta H_{12}, \mathrm{~cm} \mathrm{H}_{2} \mathrm{O}\right)$ is shown in Fig. 3. The setup consists of a horizontally placed plexiglass tube (holding the experimental worm) with the open ends each connected to an upright tube, one of which is high i.e. extends above the water line. The high tube is inserted into a collecting device with an outlet tube draining water pumped by the worm to a measuring cylinder By means of the adjustable holder a certain known hydrostatic back pressure ( 0 to $25 \mathrm{~cm} \mathrm{H}_{2} \mathrm{O}$ ) could be imposed between the inlet and outlet end of the worm-tube.

Respiration. Prior to measurement of respiration rate, lugworms of different sizes were transferred to lightly curved glass tubes of suitable inner diameter (see

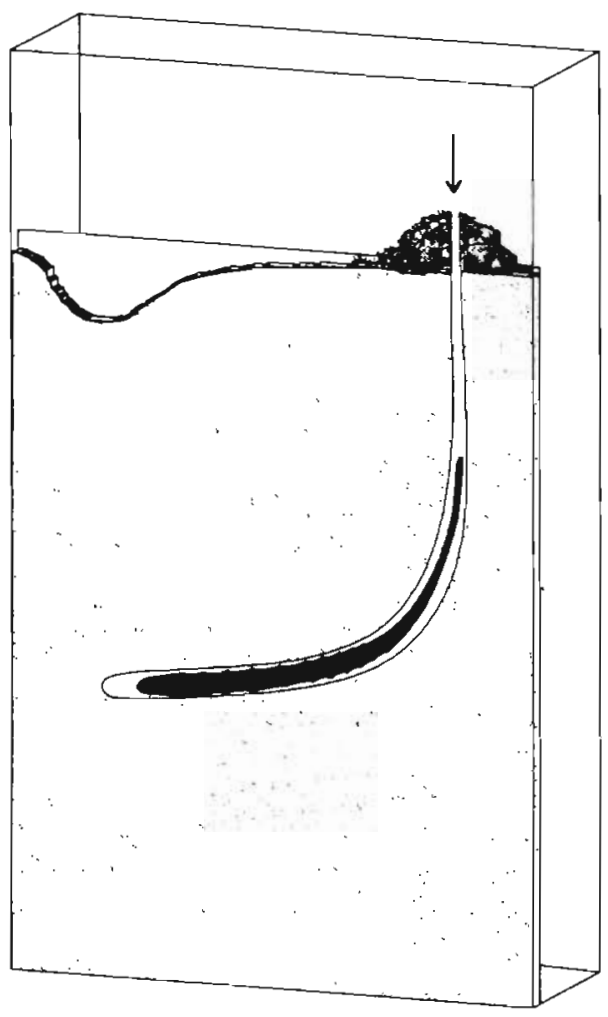

Fig. 1. Arenicola marina Observation aquarium used for monitoring the stroke frequency of the undisturbed lugworm in its natural J-shaped tube. Arrow indicates the direction of current from inlet at faeces pile to exit through the eating funnel

below). A glass tube holding a worm was in turn placed in a respiration chamber $(9 \times 5.9 \times 1.8 \mathrm{~cm})$ with an inserted oxygen electrode connected to an oxygen monitor (WTW, microprocessor based oximeter, OXI 196) and a recorder (Servogor S). A. magnetic stirrer (Oximeter-RZ 90) was mounted close to the membrane of the electrode. During each respiration measurement (approximately $30 \mathrm{~min}$ ) the decreasing dissolved oxygen tension was continously monitored, and at the same time the stroke frequency of the pumping wave of the experimental lugworm was monitored every minute. A control respiration measurement, without a worm present, was performed after every second respiration measurement. The oxygen uptake rate was calculated from the decrease in dissolved oxygen tension, taking temperature, salinity and pressure into consideration.

In all experiments the inner diameter of the wormtube $(D, \mathrm{~cm})$ was selected to (approximately) fit the actual size $\left(W_{\mathrm{w}}, \mathrm{g}\right.$ wet $\left.\mathrm{wt}\right)$ of the experimental worm according to the equation: $D=0.335 W_{\mathrm{w}}{ }^{0.33}$ (over a size range of 0.6 to $5 \mathrm{~g} ; \mathrm{n}=23 ; \mathrm{r}^{2}=0.78$ ), a relationship determined on the basis of measurements of worm size and tube diameter measured in the field by means of a calliper. 


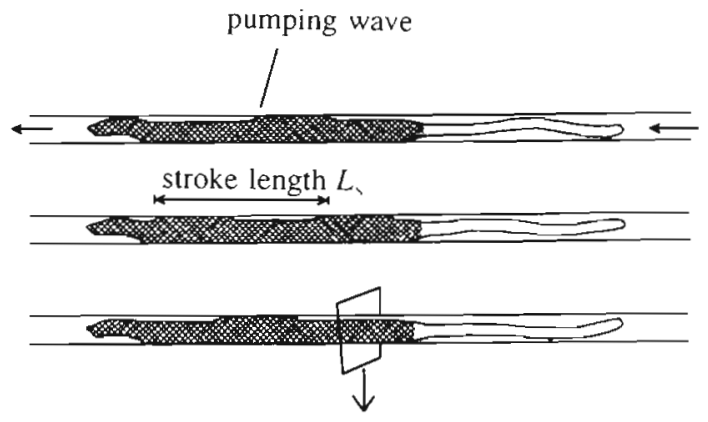

cross section

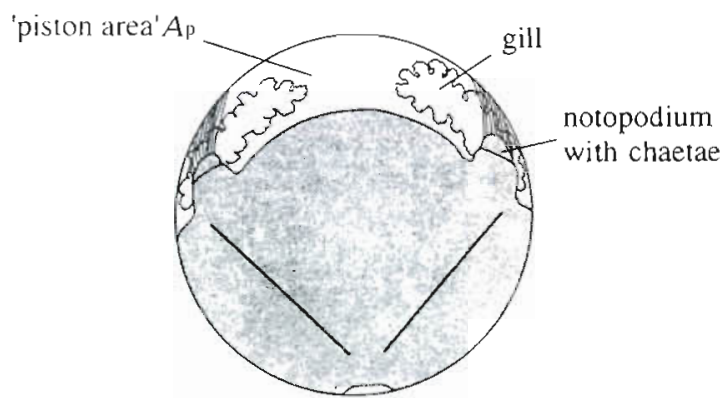

Fig. 2. Arenicola marina. Sketch illustrating the peristaltic waves of contraction and relaxation causing a tail-to-head pumping wave with a stroke length $\left(L_{s}\right)$ defined by the distance between the fronts of 2 synchronous 'piston' waves. The 'piston' area $\left(A_{\rho}\right)$ is defined by the percentage (in this case estimated to $25 \%$ ) of cross sectional area of the tube not filled up by the worm body (drawings adapted from Wells 1966)

All experiments were performed at $15^{\circ} \mathrm{C}$ and 16 to $20 \% \mathrm{~S}$ within a few days of collection.

Resistance of sediment. The frictional resistance to water flow through the sandy sediment above a pumping lugworm can be estimated by means of Darcy's law. This empirical law states that the volume flow $(Q)$ is inversely proportional to the thickness (or length $\Delta L$ ) of a core of sediment and directly proportional to the applied pressure $(\Delta H)$ and the cross-sectional area $(A)$ of the core (Riedl 1971, Fetter 1994):

$$
Q=A K \Delta H / \Delta L
$$

where the constant of proportionality $(K)$ is known as the permeability or hydraulic conductivity. The friction caused by water flow in the pore system depends upon the permeability of the sediment and has constant values for each type of deposit.

The hydraulic conductivity of rather clean sand from a site where lugworms live (Sydstranden, Kerteminde, Denmark) was experimentally determined in 2 core samples of different length and diameter (Fig. 4). The hydraulic conductivity was in the 2 cases estimated to be 4.9 and $6.6 \times 10^{-4} \mathrm{~m} \mathrm{~s}^{-1}$, respectively.

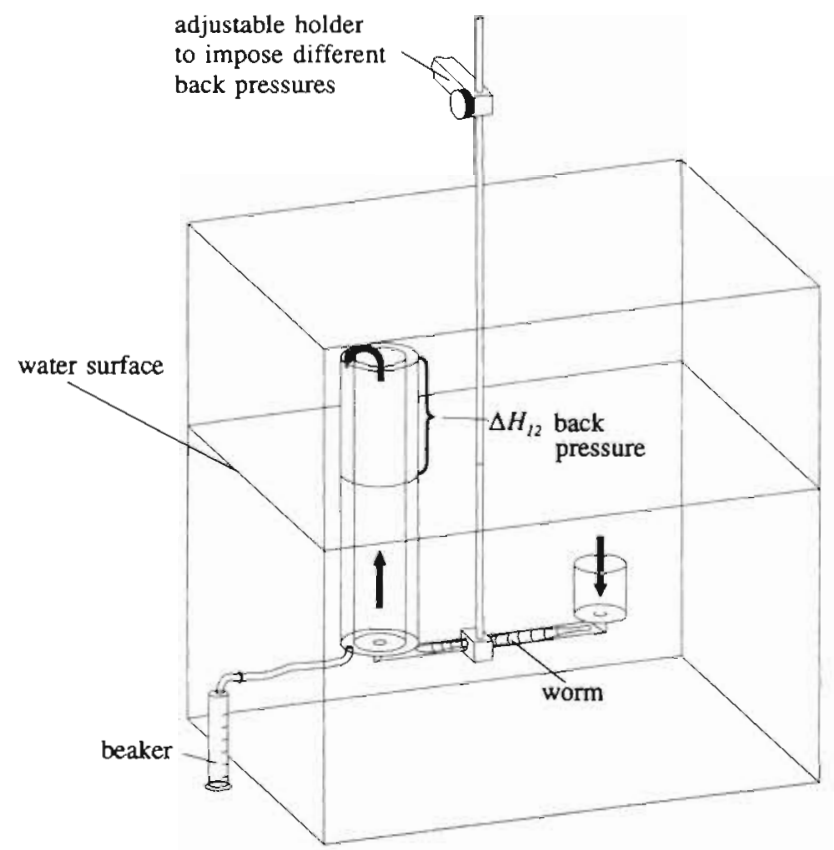

Fig. 3. Experimental setup for measurement of pumping rate (= volume flow) at different imposed back pressures for Arenicola marina. The arrows indicate direction of water flow caused by the pumping activity of the worm. The collecting device ensured drainage and quantitative collection of the pumped water

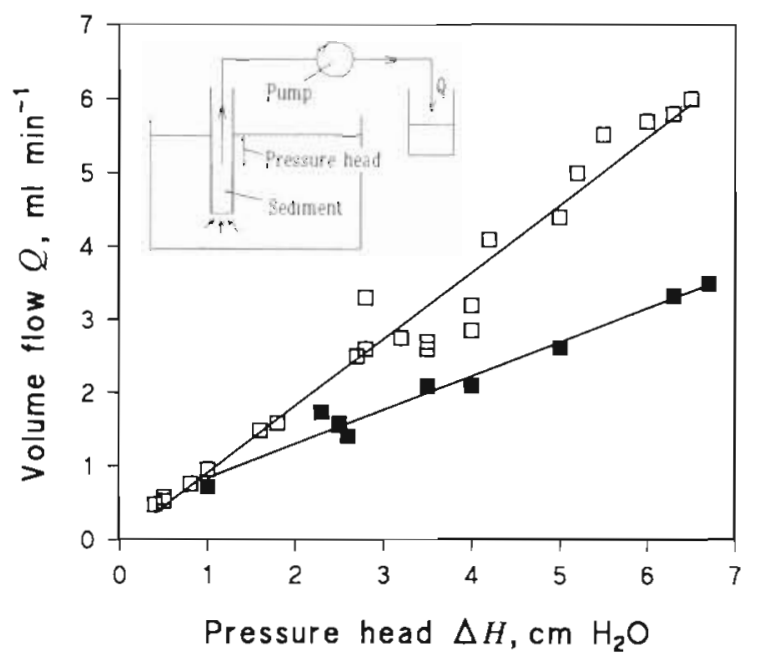

Fig. 4. Volume flow of seawater through 2 sediment cores (upper regression line: diameter $=2.64 \mathrm{~cm}$, length $=$ $17.5 \mathrm{~cm}$; lower regression line: diameter $=1.59 \mathrm{~cm}$, length $=$ $14.5 \mathrm{~cm}$ ) as a function of imposed pressure head. A sketch of the experimental setup is inserted: a pump removes all water leaking up, maintaining the water surface in the tube at the same level as the sediment surface. The imposed pressure head may be changed by vertical movement of the transparent plastic tube holding the sediment (the drawing is not to scale and the removal of water has insignificant influence on the water level in the aquarium, which determines the pressure head) 


\section{RESULTS AND DISCUSSION}

\section{Experimental results}

Fig. 5 shows the stroke frequencies monitored over $240 \mathrm{~min}$ in 9 lugworms established in the observation aquarium (cf. Fig. 1). It is notable that the pumping activity was relatively regular over extended periods, only interrupted by feeding activity or egestion of faeces to the excrement pile on the surface. The typical undisturbed stroke frequency was 6 to 7 strokes min $^{-1}$, which probably represents the normal activity in nature and was therefore used as a reference normal state in the present work.

The volume flow at zero back pressure $\left(\Delta H_{12}=0\right)$ as a function of stroke frequency $\left(f\right.$, strokes $\mathrm{min}^{-1}$ ) in worms transferred to plexiglass tubes is shown in Fig. 6. The relationship was linear, complying fairly well with the expression:

$$
Q(f)=Q_{o p}\left(f / f_{\max }\right)
$$

where $f_{\max }=$ maximal undisturbed stroke frequency and $Q_{o p}=$ resulting volume flow at the normal operating pressure head $\left(\Delta H_{\mathrm{op}}\right)$. There was a remarkable change in pumping behaviour in worms transferred to the plexiglass tubes used in the setup shown in Fig. 3 compared with the behaviour monitored in the observation aquarium (cf. Figs. 1 \& 5). In general, the activ-

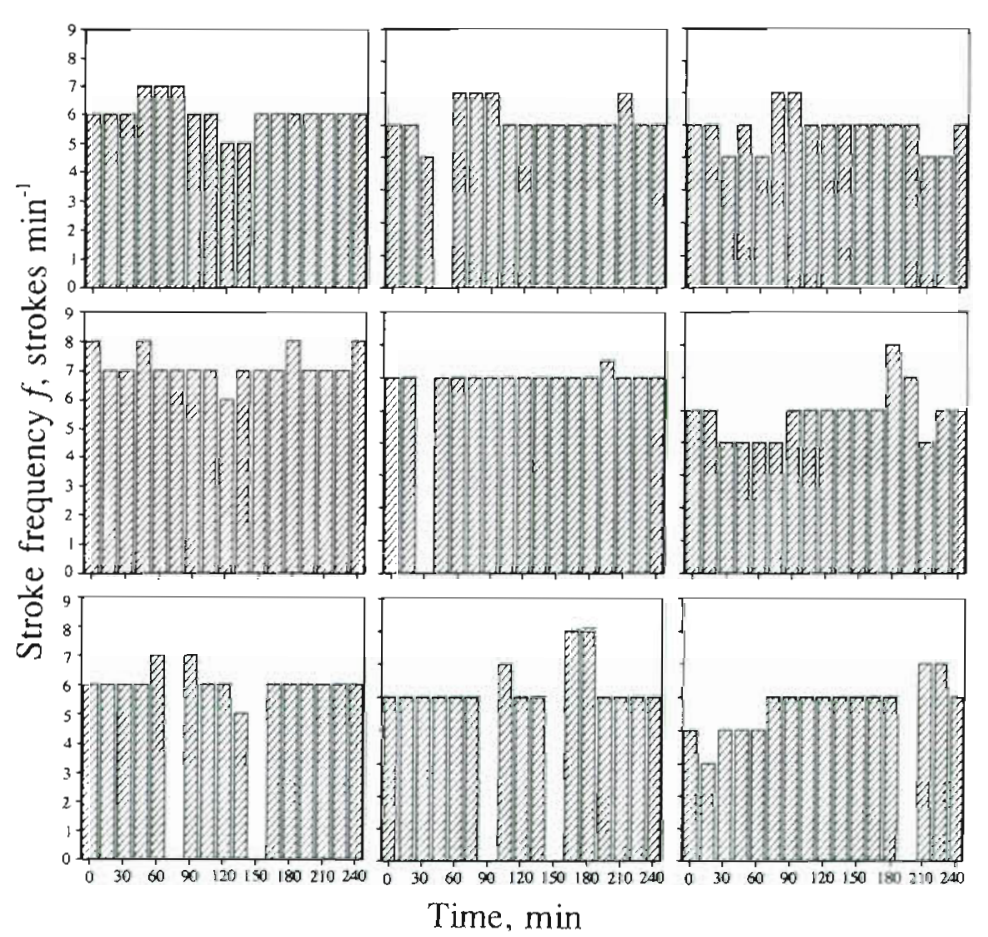

Fig. 5. Arenicola marina. Pump stroke frequencies of 9 lugworms monitored in the observation aquarium (Fig. 1) for $240 \mathrm{~min}$ ity decreased and became irregular $(3<f<10$ strokes min $^{-1}$, with shorter periods with constant frequency of 6 to 7 strokes $\mathrm{min}^{-1}$ ). This observation is of crucial importance in the further experimental analysis of the lugworm pump characteristic which strictly follows the principles and annotation advanced by Riisgård \& Larsen (1995).

Using a stroke frequency of 7 strokes $\mathrm{min}^{-1}$ as a reference for normal pumping activity, it appears that only few worms meet this demand over the prolonged period that it takes to experimentally determine the back pressure-volume flow characteristic with satisfactory reliability. Fig. 7 shows 3 representative measurements for 3 lugworms. The back pressure characteristic was a nonlinear function, the stroke frequency being reduced with increasing imposed back pressure, attaining a maximal pressure head $\Delta H_{12}{ }^{0}=20 \mathrm{~cm} \mathrm{H}_{2} \mathrm{O}$. Referring to Eq. (2), the back pressure - volume flow characteristic may therefore be modelled by the expression:

$$
\Delta H_{12}(Q)=\Delta H_{12}{ }^{0}\left[1-\left(Q(f) / Q_{\mathrm{op}}\right)^{2}\right]
$$

Curve fits, based on experimental data and Eq. (3), have been plotted for the 3 worms shown in Fig. 7 . Judging from the (satisfactory) curve fits, it is mainly the stroke frequency that controls the volume flow. The displacement volume, $D_{v}$ (stroke length, $L_{\mathrm{s}}$, multiplied by the 'piston' area, $A_{p}$ ), of the lugworm pump (see also sketch in Fig. 2) is thus constant and unaffected by internal leakage flow when the back pressure is increased.

\section{Modelling and energy cost of pumping}

To further characterize the Arenicola marina pump a 'standard' lugworm was defined according to Table 1 and Fig. 2. The pump was considered to be a closed pump ('positive displacement pump') with perfect piston seals and hence without leakage, ideally yielding a constant volume flow, $Q_{\mathrm{p}}$ (displacement volume, $D_{v}$ multiplied by strokes per unit time, $f$ ), irrespective of the pressure rise delivered: $Q_{p}=D_{v} f=A_{p} L_{p} f$.

Because the pump characteristic, $\Delta H_{p}(Q)$. is determined as the sum of pressure resistance over the pump-system, $\Delta H_{5}(Q)$, and the imposed back pressure, $\Delta H_{12}(Q)$, the following expression applies (cf. Riisgård \& Larsen 1995):

$$
\Delta H_{\mathrm{p}}(Q)=\Delta H_{\mathrm{s}}(Q)+\Delta H_{12}(Q)
$$

or referring to Eq. (3)

$$
\Delta H_{\mathrm{p}}(Q)=\Delta H_{\mathrm{s}}(Q)+\Delta H_{12}{ }^{0}\left[1-\left(Q(f) / Q_{\mathrm{op}}\right)^{2}\right]
$$



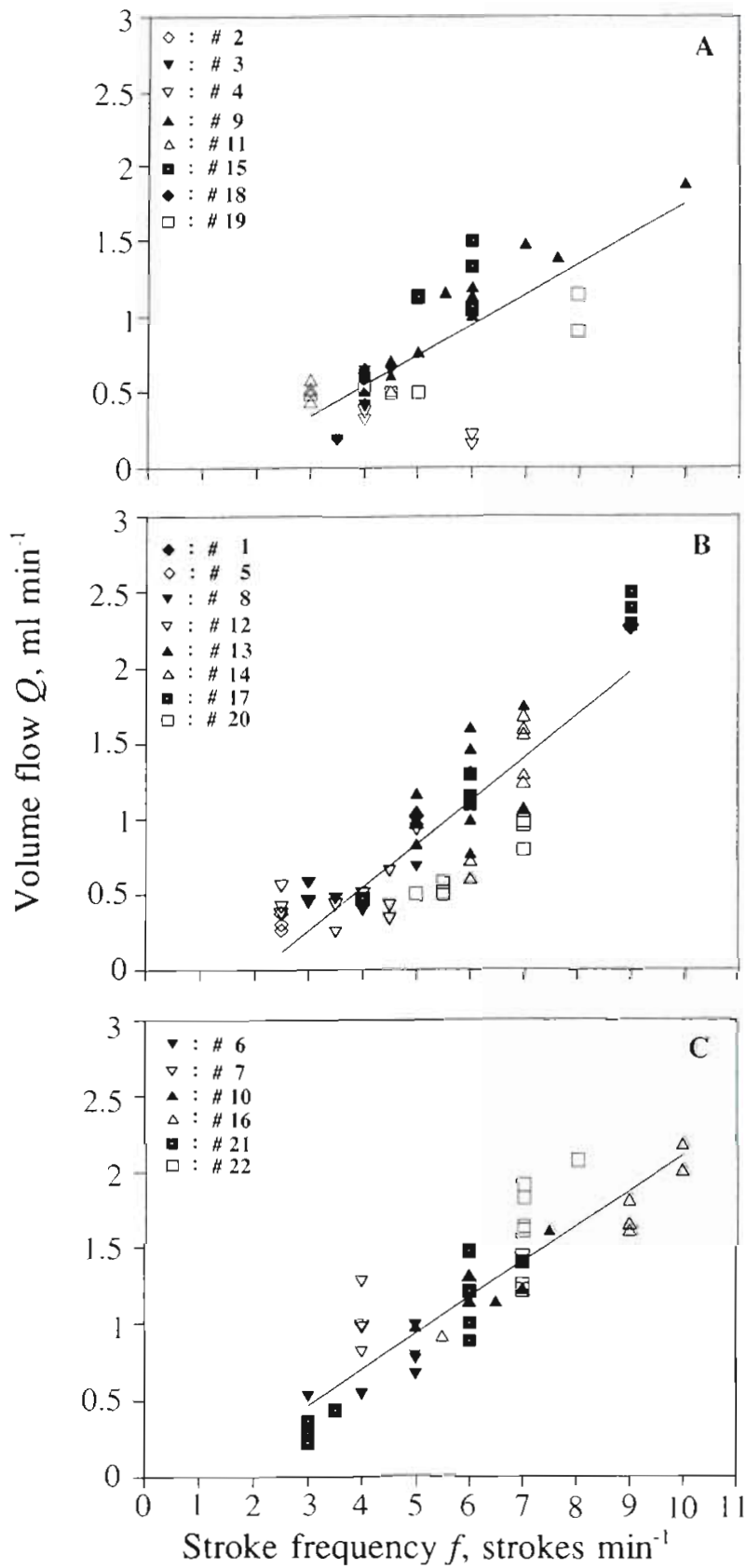

Fig. 6. Arenicola marina. Volume flow $\left(Q, \mathrm{ml} \mathrm{min}^{-1}\right)$ as a function of stroke frequency $\left(f\right.$, strokes $\left.\mathrm{min}^{-1}\right)$ in 3 size groups (A. $1.48 \pm 0.17 \mathrm{~g}$ wet wt; B: $2.41 \pm 0.16 ; \mathrm{C}: 3.55 \pm 0.21$ ) of lugworms measured at zero back pressure $\left(\Delta H_{12}=0\right)$. The equations for the regression lines shown are:
A: $Q=0.20 f-0.26\left(\mathrm{r}^{2}=0.58\right)$
$B: Q=0.28 f-0.55\left(r^{2}=0.55\right)$
$C: Q=0.23 f-0.19\left(\mathrm{r}^{2}=0.79\right)$

The system resistance, which is due to frictional resistance to flow through tube and sediment, is a linear function of flow:

$$
\Delta H_{s}(Q)=Q(f) C_{f}
$$
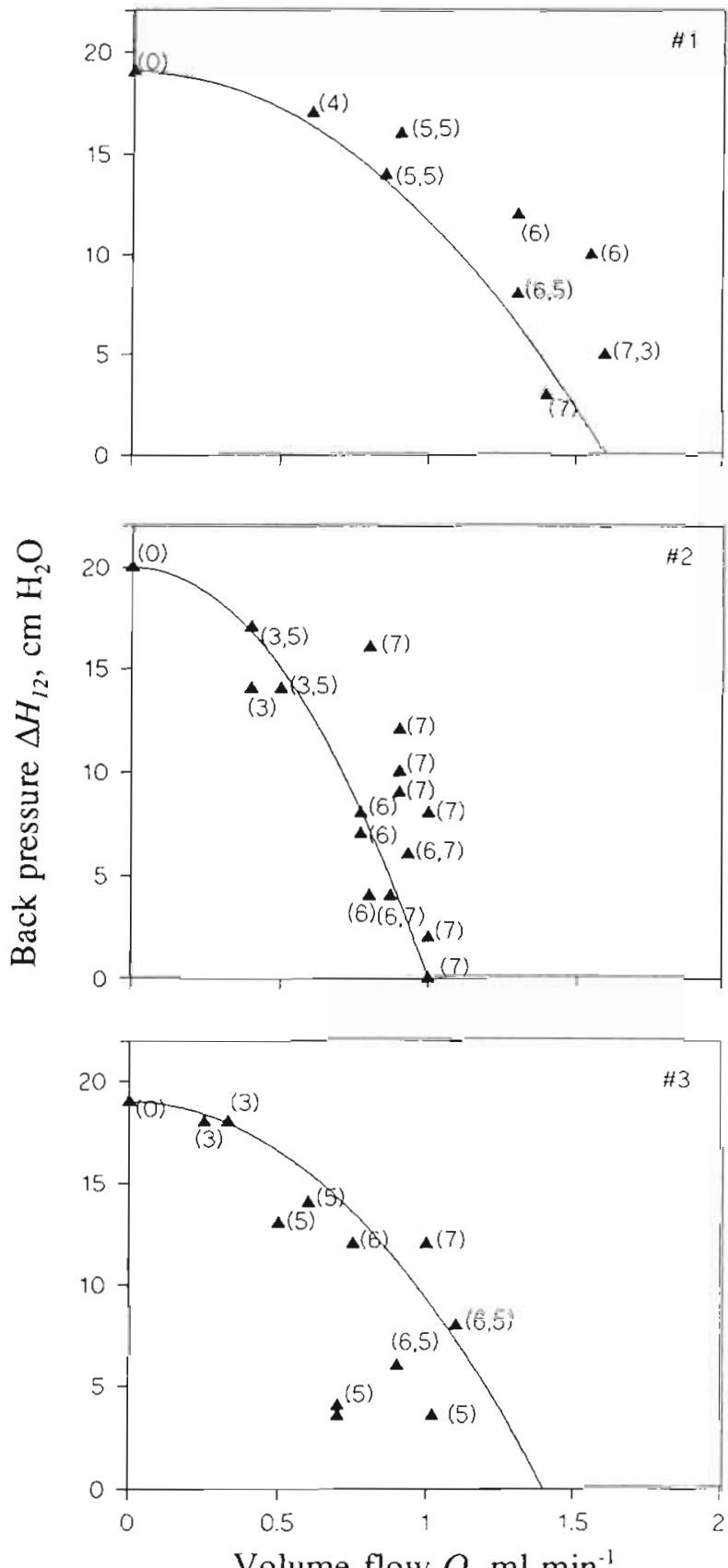

Fig. 7. Arenicola marina. Back pressure pumping rate characteristics in 3 individuals. Stroke frequency (strokes $\mathrm{min}^{-1}$ ) of the muscular piston pump, recorded simultaneously by direct measurement, is indicated in brackets. Lines were fitted by Eq. (3)

where $C_{f}$ is a constant. Thus, Eq. (4) may be expressed as:

$$
\Delta H_{\mathrm{p}}(Q)=Q(f) C_{f}+\Delta H_{12}{ }^{0}\left[1-\left(Q(f) / Q_{\mathrm{op}}\right)^{2}\right]
$$

From Eq. (7), the pumping power - volume flow characteristic of the pump, $P_{p}(Q)$, may easily be obtained as:

$$
P_{\mathrm{p}}(Q)=\rho g \Delta H_{\mathrm{p}}(Q) Q(f)
$$


Table 1. Parameters and performance of 'standard' Arenicola marina at $15^{\circ} \mathrm{C}$

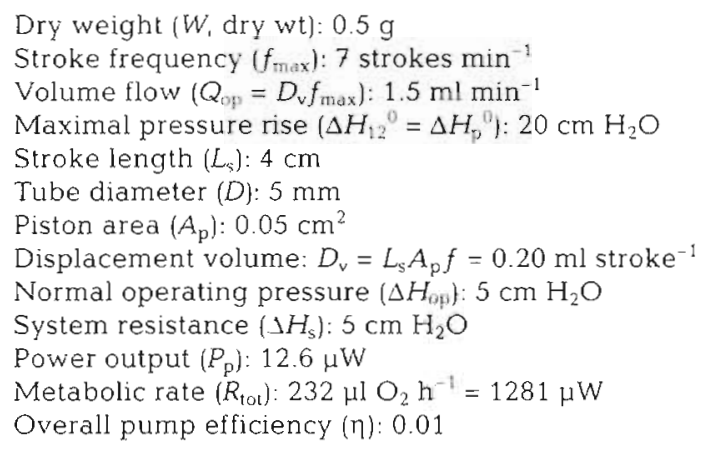

where $p=$ density of seawater, and $g=$ acceleration due to gravity.

The total resistance offered by the system of the normal active worm pump $\left(\Delta H_{\mathrm{s}}\right)$ is due to frictional resistances derived from the flow in the tube and through the space between worm body and tube wall, and the pressure drop across the sediment in the head shaft. Following the method of calculation used by Riisgård et al. (1992) for Nereis diversicolor pumping in a glass tube, it has been calculated that the total head loss of frictional resistance constitutes only $0.01 \mathrm{~cm} \mathrm{H}_{2} \mathrm{O}$ in the 'standard' Arenicola marina pumping $1.5 \mathrm{ml} \mathrm{min}^{-1}$. Thus, the resistance offered by the sediment dominates the total system resistance $\left(\Delta H_{\mathrm{s}}\right)$.

If the following parameters apply for the 'standard' Arenicola marina: $\Delta L=20 \mathrm{~cm}, A=5.5 \mathrm{~cm}^{2}$, and $K=$ $5 \times 10^{-4} \mathrm{~m} \mathrm{~s}^{-1}$, then the 'system' resistance of the sediment is calculated by Eq. (1) to be $\Delta H_{\mathrm{s}} \approx$ $2 \mathrm{~cm} \mathrm{H_{2 }} \mathrm{O}$ or $10 \%$ of the maximum pressure rise that the lugworm pump may deliver (Table 1). A realistic upper figure experienced by a normal active lugworm in nature may probably be up to $5 \mathrm{~cm} \mathrm{H}_{2} \mathrm{O}$ or $25 \%$ of its maximum pressure rise (similar to the muscular piston pump of Chaetopterus variopedatus; Riisgård 1989). Therefore, a maximum system resistance of $\Delta H_{\mathrm{s}}=5 \mathrm{~cm} \mathrm{H} \mathrm{H}_{2} \mathrm{O}$ is adopted in the present work (cf. Fig. 7 and Table 1) for further calculations. The curves for the different equations are shown in Fig 8. At the specified operation pressure $\left(\Delta H_{p}=\Delta H_{\mathrm{s}}=5 \mathrm{~cm} \mathrm{H} \mathrm{H}_{2} \mathrm{O}\right)$, the power output $\left(P_{p}\right)$ from the 'standard' lugworm pump is calculated to be $12.6 \mu \mathrm{W}$

Fig. 9 shows that the respiration rate $\left(R, \mu l \mathrm{O}_{2}\right.$ $\mathrm{h}^{1} \mathrm{l}$ in lugworms is highly correlated with dry weight $(W, g)$ and dependent on the stroke frequency. The percentages of total time spent by the worms in the different stroke activity states were: $15 \%\left(f<2\right.$ strokes min $\left.{ }^{\top}\right), 10 \%(f=$
4 or 5$), 50 \%(f=6), 15 \%(f=7), 10 \%(f=8)$. Regression analyses show that the respiration rate increases with increasing body size according to the equation $R$ $=a W^{b}$. For worms with an activity level of 7 strokes $\mathrm{min}^{-1}$ (cf. Fig. 5) it was found that $R=344 W^{0.64}\left(\mathrm{r}^{2}=\right.$ 0.97 ). For a 'standard' $0.5 \mathrm{~g}$ dry weight ( $3.5 \mathrm{~g}$ wet $w t)$ lugworm (cf. Table 1) the total respiration was estimated to be $R_{\mathrm{tol}}=232 \mu \mathrm{O}_{2} \mathrm{~h}^{-1}$, corresponding to a metabolic rate of $1281 \mu \mathrm{W}$. This value may be related to the power output from the lugworm pump $\left(P_{\mathrm{p}}=\right.$ $12.6 \mu \mathrm{W}$ ), and the overall pump efficiency is thus found to be $\eta=P_{\mathrm{p}} / R_{\text {tot }}=(12.6 / 1281) \times 100=1 \%$. Further, if the metabolic to mechanical efficiency is $20 \%$ (which is a realistic figure for muscles) this implies that the pump work constitutes $(5 \times 12.6 / 1281) \times 100=5 \%$ of the total metabolic power output when Arenicola marina is exploiting $25 \%$ of the maximal pressure head which may be delivered by its pump.

\section{Ecological implications}

It is unknown if or when Arenicola marina exploits the full capacity of its pump. The maximal pressure head delivered by the lugworm pump is $\Delta H_{p}{ }^{0}=\Delta H_{12}{ }^{0}=$ $20 \mathrm{~cm} \mathrm{H} \mathrm{H}_{2} \mathrm{O}$ which is 30 to 150 times higher than found in filter-feeding macro-invertebrate pumps (Riisgård \& Larsen 1995). The latter group is characterized by the pumping of large amounts of water per ml of oxygen consumed. Thus, the filter-feeding polychaetes Sabella penicillus, Chaetopterus variopedatus and Nereis diversicolor pump 354, 50 and $40 \mathrm{l}$ of water per $\mathrm{ml}$ of

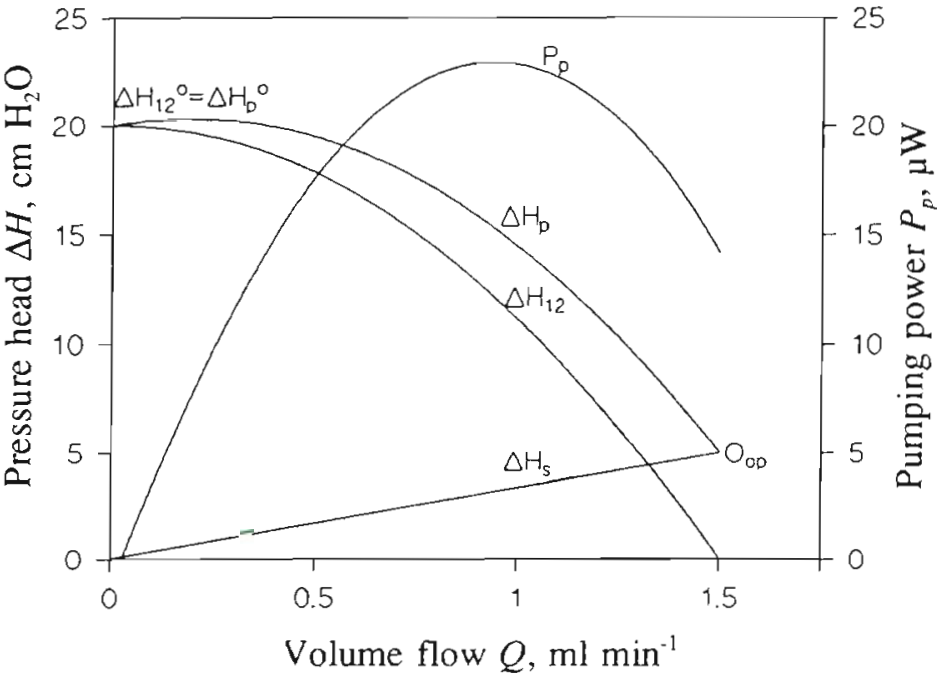

Fig. 8. Arenicola marina. Pressure head-pumping rate characteristics for pump pressure $\left(\Delta H_{p}\right)$, system resistance $\left(\Delta H_{s}\right)$ and back pressure $\left(\Delta H_{12}\right) . P_{\mathrm{p}}$ : pumping power - pumping rate characteristic of the pump $O_{o p}$ : normal operating point. The calculations are based on a standard' Iugworm, cf. Table 1 


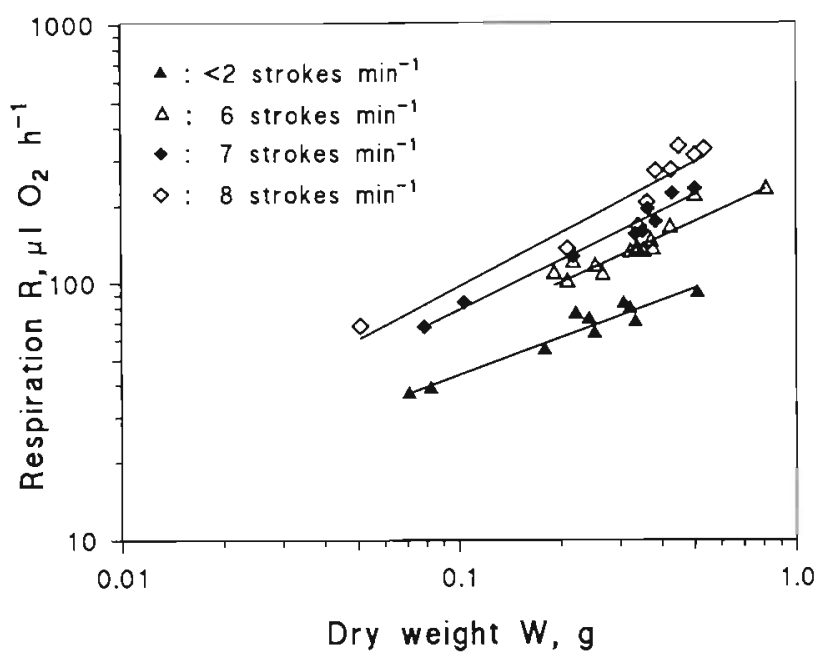

Fig. 9. Arenicola marina. Respiration rate $\left(R, \mu l \mathrm{O}_{2} \mathrm{~h}^{-1}\right)$ as function of dry weight $(W, g)$ of lugworms. At defined stroke frequency $\left(f\right.$, strokes $\left.\mathrm{min}^{-1}\right)$, the regression constants for the equation $R=a W^{b}$ are:

$$
\begin{aligned}
& f<2: \quad a=133.6, b=0.49\left(\mathrm{r}^{2}=0.92\right) \\
& f=6: \quad a=262.9, b=0.60\left(\mathrm{r}^{2}=0.86\right) \\
& f=7: \quad a=344.0, b=0.64\left(\mathrm{r}^{2}=0.97\right) \\
& f=8: \quad a=433.5, b=0.69\left(\mathrm{r}^{2}=0.90\right)
\end{aligned}
$$

oxygen consumed, respectively (Riisgård \& Larsen 1995). These values may be compared with $(1.5 \times 60 \times$ $10^{-3}$ ) $/ 0.232=0.4 \mathrm{l} \mathrm{ml}^{-1} \mathrm{O}_{2}$ in the 'standard' A. marina. This very low value shows that it is unlikely that the lugworm can make a living as a filter-feeder, using the sand immediately in front of the head as a particle retaining filter for restraining suspended food particles in the ventilatory water, as proposeed by Krüger (1959).

The energetics of the piston pump of Arenicola marina has previously been assessed by Toulmond \& Dejours (1994) to be about $50 \%$ of the total metabolic energy costs. This high 'cost of breathing' arose from the authors' erroneous assumption that the measured increased oxygen uptake rate at increased ventilatory flow rate was due to enhanced energy expenses of pumping. At low pumping rates the oxygen uptake is entirely dependent on the renewal of water close to the gills. Simultaneously with an increased ventilatory flow rate (higher stroke frequency) the oxygen concentration boundary layer along the gill surfaces is reduced, thus enhancing the oxygen uptake rate (Jørgensen et al. 1986b, Jørgensen 1990, 1992). The lack of differences between uptake rates at 2 inserted system resistances in the work of Toulmond \& Dejour (1994, their Fig. 2) is apparently self-contradictory - but not in conflict with the alternative interpretation. It is believed that the observed correlation between respiration rate and stroke frequency is mainly due to nonsteady-state oxygen uptake conditions caused by unsteady pumping activity of lugworms kept in glass tubes.

The present work shows that the energy cost of pumping by Arenicola marina is modest $(<5 \%)$, especially in a loose sediment. On the other hand the powerful pump may at times (presumably over shorter periods) be used for loosening a compact sediment (Wells 1966, Foster-Smith 1978). In this way a high initial system resistance may be reduced to a relatively low value during the normal ventilatory state which is characterized by a steady and continuous stroke frequency of about 7 strokes $\mathrm{min}^{-1}$.

Acknowledgements. The work was conducted as part of the Danish Environmental Research Programme 1992-1996. Centre for Strategic Environmental Research in Marine Areas. Thanks are due to C. Barker Jørgensen, Gary Banta, and Lilian Skjernaa who passed remarks on the manuscript.

\section{LITERATURE CITED}

Baumfalk YA (1979) On the pumping activity of Arenicola marina. Neth J Sea Res 13:422-427

Cadée GC (1976) Sediment reworking by Arenicola marina on tidal flats in the Dutch Wadden Sea. Neth J Sea Res 10 : $440-460$

De Wilde PAWJ, Berghuis EM (1979) Growth experiments on juvenile lugworms, Arenicola marina, in the laboratory. Neth J Sea Res 13:487-502

Fetter CW (1994) Applied hydrogeology. MacMillan, New York

Foster-Smith RL (1978) An analysis of waterflow in tubeliving animals. J Exp Biol Ecol 34:73-95

Hobson K (1967) The feeding and ecology of two North Pacific Abarenicola species (Arenicolidae, polychaeta). Biol Bull Mar Biol Lab, Woods Hole 133:343-354

Hylleberg J (1975) Selective feeding by Abarenicola pacifica with notes on Abarenicola vagabunda, and a concept of gardening in lugworms. Ophelia 14:113-137

Jacobsen VH (1967) The feeding of the lugworm Arenicola marina. Quantitative studies. Ophelia 4:91-109

Jørgensen CB, Famme P, Kristensen HS, Larsen PS, Møhlenberg F, Riisgard HU (1986a) The bivalve pump. Mar Ecol Prog Ser 34:69-77

Jørgensen CB, Møhlenberg F, Steen-Knudsen O (1986b) Nature of relation between ventilation and oxygen consumption in filter feeders. Mar Ecol Prog Ser 29:73-88

Jorgensen CB (1990) Bivalve filter feeding: hydrodynamics, bioenergetics, physiology and ecology. Olsen \& Olsen, Fredensborg

Jorgensen CB (1992) Adaptational, environmental, and ecological physiology. A case for hierachial thinking. In: Wood SC, Weber RE, Hargens AR, Millard RW (eds) Physiological adaptations in vertebrates, respiration, circulation and metabolism. Marcel Dekker Inc, New York, p 9-17

Krüger F (1959) Zur Ernährungsphysiologie von Arenicola marina (L.). Zool Anz 22:115-120

Krüger F (1962) Experimentelle Untersuchungen zur ökologischen Physiologie von Arenicola marina. Kieler Meeresforsch 18:157-168

Krüger F (1964) Messungen der Pumptätigkeit von Arenicola marina L. im Watt. Helgoländer Wiss Meeresunters 1. $70-91$ 
Larsen PS, Riisgård HU (1994) The sponge pump. J Theor Biol 168:53-63

Newell GE (1948) A contribution to our knowledge of the life history of Arenicola marina. J Mar Biol Ass UK 27:554-580

Pollack H (1979) Populationsdynamik, Produktivität und Energiehaushalt des Wattwurms Arenicola marina (Annelida, Polychaeta). Helgoländer Wiss Meeresunters 32: 313-358

Riedl R (1971) How much seawater passes through sandy beaches? Int Rev Ges Hydrobiol 56:923-946

Riisgård HU (1988) The ascidian pump: properties and energy cost. Mar Ecol Prog Ser 47:129-134

Riisgård HU (1989) Properties and energy costs of the muscular piston pump in the suspension feeding polychaete Chaetopterus variopedatus. Mar Ecol Prog Ser 56: $157-168$

Riisgård HU (1994) Filter-feeding in the polychaete Nereis diversicolor a review. Neth J Aquat Ecol 28:453-458

Riisgârd HU, Ivarsson NM (1990) The crown-filament pump of the suspension-feeding polychaete Sabella penicillus: filtration, effects of temperature, and energy cost. Mar Ecol Prog Ser 62:249-257

Riisgård HU, Thomassen S, Jakobsen $\mathrm{H}$, Weeks J, Larsen PS (1993) Suspension feeding in marine sponges Halichondria panicea and Haliclona urceolus: effects of temperature on filtration rate and energy cost of pumping. Mar Ecol Prog Ser 96:177-188

Riisgård HU, Larsen PS (1995) Filter-feeding in marine macro-invertebrates: pump characteristics, modelling and energy cost. Biol Rev 70:67-106

This article was submitted to the editor
Riisgård HU, Vedel A, Boye H, Larsen PS (1992) Filter-net structure and pumping activity in the polychaete Nereis diversicolor: effects of temperature and pump-modelling. Mar Ecol Prog Ser 83:79-89

Rijken M (1979) Food and food uptake in Arenicola marina. Neth J Sea Res 13:406-421

Seymour MK (1971) Burrowing behaviour in the European lugworm Arenicola marina (Polychaeta: Arenicolidae). $\mathrm{J}$ Zool Lond 164:93-132

Toulmond A, Dejours P (1994) Energetics of the ventilatory piston pump of the lugworm, a deposit-feeding polychaete living in a burrow. Biol Bull 186:213-220

Van Dam L (1937) Über die Atembewegungen und das Atemvolumen von Phryganea-Larven, Arenicola marina und Nereis virens, sowie über die Sauerstoffausnutzung bei Anodonta cygnea, Arenicola marina und Nereis virens. Zool Anz 118:122-138

Wells GP (1949a). Respiratory movements of Arenicola marina: Intermittent irrigation of the tube, and intermittent aerial respiration. J Mar Biol Ass, UK 28:447- 464

Wells GP (1949b) The behaviour of Arenicola marina in sand, and the role of spontaneuos activity cycles. J Mar Biol Ass, UK 29:1-44

Wells GP (1951) The integration of activity cycles in the behaviour of Arenicola marina. J Exp Biol 28:41-50

Wells GP (1961) How lugworms move. In: Ramsay JA, Wrigglesworth VB (eds) The cell and the organism. Cambridge, p 209-233

Wells GP (1966) The lugworm (Arenicola) - a study in adaptation. Neth J Sea Res 3:294-313

Manuscript first received: November 30, 1995

Revised version accepted: March 27, 1996 